http://dx.doi.org/10.4314/jae.v15i2.7

\title{
Commodity Alliance Model - An Option for Advancing Private and Commercial Extension Service Delivery in Nigeria
}

\author{
${ }^{*}$ Ademola A. Ladele ${ }^{1}$ and Gbolagade B. Ayoola ${ }^{2}$ \\ ${ }^{1}$ Department of Agricultural Extension and Rural Development, University of Ibadan, Ibadan Ph: \\ 08038565629, E-mail: aaladele@yahoo.com \\ ${ }^{2}$ The Farm and Infrastructure Foundation (FIF), 38 Panama Street, Ministers Hill, Maitama, Abuja
}

\begin{abstract}
Despite improved technologies and several extension approaches being tried in Nigeria, arable croppers' productivity has been consistently low. Moreover farmers are usually not totally enthusiastic about sustained use of proven technologies due to unfavorable economic and policy environment within which they operate. More than ever before, farmers are being careful to produce only what they have been assured market for. Meanwhile, processors and produce-buyers are in short supply of raw materials. The government operated public extension tends to give much attention to production and less to post harvest handling and marketing. To induce farmers to produce optimally, effective innovative approaches to production and marketing that ensure adequate value addition and ultimate remunerative price for farmers' produce would have to be in place. The presidential initiatives on cassava and rice have expanded the markets such that producers need inducement and special assistance from relevant agri-service providers in marketing their produce. To derive the desired impact of cassava initiative on the national economy, an efficient and well-integrated production and marketing system is necessary to assure a steady supply of cassava products to domestic industries and European markets. It is also in the same vein that rice producers need to be more structured in their production agenda and be assured of their produce markets. One of the innovative approaches being applied to boost cassava and rice production in Nigeria is the use of groups of out-growers. Several lessons have been learnt from two different cases in contract farming. The lessons culminated in an innovative private extension model where independent extension agency brokers an effective production and marketing environment for income yielding commodities. Based on the lessons learnt from selected projects, the Farm and Infrastructure Foundation (FIF) has packaged a strengthened commodity - alliance model for sourcing raw materials for agro-based companies using out-growers in Nigeria. In this innovative model FIF as an independent organization creates a platform for effective linkage of markets and farmers for each commodity, and integrating them in terms of fair price determination, information flow and issues resolution. The FIF model will create an in-road for strengthening private extension practice in Nigeria.
\end{abstract}

Keywords: Commercialization, commodity alliance model, extension service delivery, farm and infrastructure foundation and privatization.

\section{Introduction}

Agricultural extension in Nigeria has a checkered history, which in effect has affected the performance of the nation's agriculture sector as a whole. A quick overview could be traced from the colonial era when there was limited extension-able technology 
with focus mainly on cash crops development as raw materials for the European fledging industries. Next is the post-colonial period in the 1960s, when extension service delivery was ministry-based with attendant problems of non-performing structures and poor linkages, until the mid-1970s when the project-based extension outfit, using the Training and Visit Extension System was adopted. While it is apt to say that the Agricultural Development Project [ADP] model persists till date, it has undergone several reforms and adaptation.

In effect, various extension approaches adopted have not significantly transformed the agricultural and rural landscape. The contribution of agriculture to the gross domestic product [GDP] which averaged $56 \%$ in the 1960 s, dropped to about $32 \%$ in the 1970 s and stood at $48 \%$ in the 1980 s. After a slight increase to $49 \%$ in the 1990 s it dropped again to $47 \%$ in the 2000s (NBS, 2000). On a more discrete note, agriculture contributed only $32.5 \%$ in 2009 and 31.9\% in 2010 (CIA World Factbook, 2010).

Despite consistent dependence on oil as the main source of revenue and persistent neglect of agriculture, it continues to be the mainstay of the Nigerian economy. Amidst of efforts to 'get agricultural moving' through various development interventions largely driven by international donor agencies, various lessons are learnt on how the agriculture sector could better perform and how agricultural extension could better be applied. It is on this basis that the Commodity Alliance Model was designed and considered as a channel through which commercial and privatized extension service delivery could be achieved.

This paper is articulated based on the following sections. The first section presents the rationale for market-focused extension. Cases of crops on which significant boost in productivity have been achieved as exemplified by cassava and rice are presented in section two. Section three presents the Commodity Alliance Model and its application is presented in section four. Conclusion is finally drawn in section five.

\section{Rationale for Market-Focused Extension}

Subsistence farming is fast fading away and being replaced with commercial agriculture in which even small farm holders have the market as the major target of their production agenda. However, the goal is often frustrated when farmers have bumper harvest only to discover that no remunerative price is offered. It is in this circumstance that USAID/NIGERIA MARKETS (2005) focuses on agro-business development using a Commodity Alliance Strategy, 'recognizing that demand in form of a specific buyer is the major force to ensure improvements in on-farm productivity resulting in increased, sustainable rural incomes. This strategy is largely justified on account of assured market and payment of remunerative price being major incentives to farmers' productive capacity. Disincentive generated by dearth of guaranteed market for farm crops is best illustrated with cassava resulting in a cyclic cob- web of scarcity and glut in supply. It could also be argued that additional effort into improved farm yield is not wise until postharvest loss put at $20-40 \%$ is greatly reduced by value addition achievable through appropriate marketing functions (Nkama, Adamu and Igene, 1994).

On another consideration, the focus of extension on production with less attention on post-harvest handling amount to creating half-baked entrepreneurs because the job of an entrepreneur is incomplete until the good finally gets to the final 
consumers. This is an area where small farmers are left at the mercy of shylock itinerant buyers who make better profit without actually performing satisfactory functions.

It is apt to ask if the public extension service delivery system in Nigeria could be stretched against the background of the current outlay of facilities and capacity to assume the duty herein expressed. This paper attempts to capture, and document evidence of effective boost in certain crops productivities and use it is as basis for providing a plausible option toward achieving commercialization and privatization of extension service delivery in Nigeria.

\section{Recent Development in Cassava and Rice Development}

The on-farm yields of many crops have been continually lower compared to what are achievable as demonstrated by research stations' adaptive plots. And unless such gaps are closed up on sustainable basis, eradication of extreme poverty and hunger could be largely unrealistic. This dismal performance of Africa based on the MDG Report 2010 to achieve the goals so far makes the theme of this conference to be topical [Audinet.and Haralambous, 2005]. Agricultural Extension has a pivotal role to play in the development interventions in whichever formation they might choose to come. A brief overview of cassava and rice production in Nigeria is thus presented.

\section{The Cassava Transformation in Nigeria}

Nigeria is the largest producer of cassava in the world with about 38 metric tons per year ahead of Brazil and Thailand (Ashaye et al, 2005). With only 7.8 metric tons of cassava produced in Nigeria in the early 1960s and the current 2009 in 2009, it is easy to agree that the country has really experience transformation in Nigeria. Nweke (2004) ascribes the transformation to four key factors including 'the IITA's new high-yielding Tropical Manioc Selection (TMS) varieties, high consumer demand for cassava, the use of the mechanical grater to prepare gari released labor, especially from processing for planting more cassava and lastly, the Africa-wide biological control programme which averted the devastating mealy-bug epidemic'.

The fact that cassava yield still hovers around between $10-15$ tons/ha, falls short of the potential yield of 30 tons/ha suggests that extension service has a significant role to play. This position is further reinforced by the fact that there is demand for more cassava to reduce extreme hunger and open doors for export and industrial use of the crop. Nweke (2004) reports that, only $7.0 \%$ of total Africa cassava production is utilized industrially while the remaining $93.3 \%$ is consumed as food. If the cyclic glut and boom in the cassava industry can be eradicated through assured market for the produce, cassava alone could significantly contribute to the achievement of the $1^{\text {st }}$ MDG in Nigeria. This was the spirit behind the launching of Presidential Initiative on cassava. 
Table 1: World cassava production (Food Outlook, 2009)

\begin{tabular}{|c|c|c|c|c|}
\hline & 2006 & 2007 & $2008^{*}$ & $2009^{\star *}$ \\
\hline & \multicolumn{4}{|c|}{ 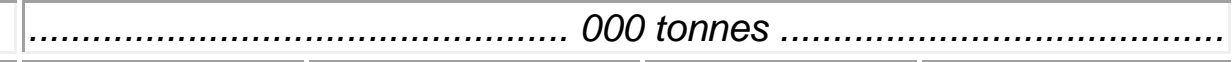 } \\
\hline WORLD & 224483 & 217536 & 233391 & 242069 \\
\hline Africa & 117449 & 104952 & 118461 & 121469 \\
\hline Nigeria & 45721 & 34410 & 42770 & 45000 \\
\hline Congo, Dem. Rep. of & 14989 & 15004 & 15020 & 15036 \\
\hline Ghana & 9638 & 9650 & 9700 & 10000 \\
\hline Angola & 8810 & 8800 & 8900 & 9000 \\
\hline Mozambique & 6765 & 5039 & 8400 & 9200 \\
\hline Tanzania, United Rep.o & ff 6158 & 6600 & 6700 & 6500 \\
\hline Uganda & 4926 & 4456 & 4942 & 4500 \\
\hline Malawi & 2832 & 3239 & 3700 & 4000 \\
\hline Madagascar & 2359 & 2400 & 2405 & 2000 \\
\hline Other Africa & 15251 & 15354 & 15923 & 16233 \\
\hline Latin America & 36311 & 36429 & 37024 & 36606 \\
\hline Brazil & 26639 & 26541 & 26600 & 26000 \\
\hline Paraguay & 4800 & 5100 & 5300 & 5400 \\
\hline Colombia & 1363 & 1288 & 1444 & 1500 \\
\hline Other (Latin America) & 3509 & 3500 & 3680 & 3706 \\
\hline Asia & 70465 & 75882 & 77631 & 83715 \\
\hline Thailand & 22584 & 26411 & 25156 & 30088 \\
\hline Indonesia & 19987 & 19988 & 20269 & 20500 \\
\hline Viet Nam & 7783 & 7985 & 8300 & 8600 \\
\hline India & 7620 & 8429 & 8959 & 9200 \\
\hline China, mainland & 7500 & 7875 & 8300 & 8700 \\
\hline Cambodia & 2182 & 2215 & 3604 & 3275 \\
\hline Philippines & 1757 & 1871 & 1941 & 2200 \\
\hline Other Asia & 1053 & 1108 & 1102 & 1151 \\
\hline Oceania & 258 & 272 & 275 & 280 \\
\hline
\end{tabular}

${ }^{*}$ Estimate

${ }^{\star *}$ Forecast 
The initiative has further boosted cassava production up to 45 metric tons in 2006 but as predicted by Ayoola (2007) 'the gains of the Initiatives has not been sustained because Nigeria has not secured the outlets for disposing the outputs as the anticipated export market is sluggish in opening up thereby creating a glut'. This is confirmed by the production figures of 2007 that dropped to $34 \mathrm{~m}$ tons; though, it has climbed back by 2007 estimate (see Table 1). As a result various strategies are being packaged to strengthen cassava farmers' productive capacity.

The presidential initiatives on cassava and rice have expanded the markets such that producers need inducement and special assistance from relevant agri-service providers in marketing their produce. To derive the desired impact of cassava initiative on the national economy, an efficient and well-integrated production and marketing system is necessary to assure a steady supply of cassava products to domestic industries and European markets (Nweke, 2004). It is also in the same vein that rice producers need to be more structured in their production agenda and be assured of their produce markets.

One of the innovative approaches being applied to boost cassava and rice production in Nigeria is the use of groups of out-growers. Several lessons have been learnt from two different cases in contract farming. The lessons culminated in an innovative private extension model where independent extension agency brokers an effective production and marketing environment for income yielding commodities.

\section{The case of cassava}

Ekha Agro Farms Nig. Ltd is an indigenous agro-allied firm involved in the processing of cassava fresh tubers into glucose syrup for pharmaceutical and confectionery use in Nigeria. The capacity of the processing plant utilizes 400 metric tons of fresh cassava tubers to produce 80 metric tons of glucose syrup per day.

To ensure a constant and consistent supply of raw materials, the firm has cassava plantations as well as contractual agreements with smallholder farmers within Ogun, Oyo and Osun States. Within the first two years of the establishment of the contract growers, scheme (2004 - 2006), 850 hectares of cassava have been established by smallholder farmers in the three states. The linkage assists cassava growers to produce under a guaranteed market scheme. Using grouping of farmers, facilitation and pricing policy [ $50 \%$ of cost price as mark-up for selling produce], the scheme has demonstrated certain strengths. Ekha [i] has farmers' groups of a maximum of 30 members per group at various locations in the three states. Each member of the group has a minimum of 2 ha of Cassava farm; [ii] the scheme helps to promote, coordinate and provide ready market for cassava fresh tubers with fixed and guaranteed pricing structure; [iii] provides farmers with a range of managerial, technical and extension services, which are sometimes unobtainable otherwise; [iv] the contractual agreement between the firm and the farmers have been used as collateral to arrange for credit with input suppliers and commercial banks and [v] pricing policy is considered very favourable when compared with the present prevailing market price and fluctuations. The scheme's weaknesses center around: [i] poor management and consultation often lead farmers to discontent; [ii] timeliness of provision of inputs and evacuation of farm produce; and [iii] low facilitation skills of personnel results in the 
weakness of working with groups. Therefore, sustainability of this approach is in doubt unless these gaps are filled.

\section{The case of rice}

The second case study pertains to the USAID/NIGERIA MARKETS-sponsored study Evaluation of Rice Alliance Project in Nigeria, which provided additional lessons in filling the gap identified. The study assessed the soundness of the Rice Alliance pilot project and the overall efficiency and effectiveness of the Alliance model. In this model, 1665 farmers were organized into 105 groups, which received packages of inputs and credit from an alliance of suppliers, based on loose relations between interested members. According to the AIAE Report [2005], the project brought comprehensive and holistic package of inputs, credit, and training; and market arrangements to the doorsteps of farmers. The use of farmers' groups encouraged organizational development in the local community and overall, the project demonstrated significant potentials of private sector-led approach for transforming the production and marketing of rice. However, the project suffered a weakness of poor coordination [monitoring, supervision and feedback] due to lack of vital brokering role, independent extension organization could have played.

Also, under the Public-Private Partnership of USAID/MARKETS/Olam Nigeria Limited that commenced in 2006, rice yield has increased from 1.25 to 3.25 metric tons per ha on the farmers' field. The varieties of rice in use are FARO 44 and FARO 52. On model farms, used to demonstrate the technology to farmers, there were increase in size from 22 to 100 ha with recorded yields ranging from 3 to 6.5 metric tons per ha. From the intervention, farmer's income was more than doubled. Also Olam Nigeria Limited - a rice milling firm in Benue State which was challenged with insufficient supply of high quality paddy rice to meet its 18,000 ton capacity has upgraded to 36,000 metric tons per annum. In view of the success of this partnership, Olam Nigeria Limited was one of the ten winners of the 2008 World Business and Development Awards [WBDA], sponsored by the United Nations Development Program [UNDP], the International Chamber of Commerce and the International Business Leaders' Forum. This pilot project is being replicated in Kwara State and hopefully will scale-up to all rice growing areas of the country.

\section{The Commodity Alliance Model}

The Commodity Alliance Model as packaged by FIF is called 'Business Partnership Model' [BPM]. It has root in Public-Private-Partnership [PPP] theories and lessons from several pilot studies, especially the MARKETS' works on Commodity Alliance Strategy [CAS].

The key elements include:

1. Backward integration programme: This involves the private sector operating strictly for business and profit. In order to ensure returns of its investment and remain in business, private sector organization has as a priority to look for means of enhancing their services by partnering with farmers, input suppliers and other farm services providers and as well adapting these to their clientele changing requirements and expectations. 
The vast majority of farmers in sub-Saran Africa do not generate sufficient income from agriculture to provide basic nutrition, health, education or living conditions for their families, yet alone to re-invest in their farms.

2. The purpose of partnership: the purpose of the partnership must involve securing raw materials supply to identified users and supplying the commodity at price remunerative to farmers and in the long run making agricultural inputs accessible and affordable to end users.

3. Key stakeholders: The stakeholders in the standard FIF BPM for any commodity are Target Farmers [in commodity group], Users' company, Partnership Manager, Farm Input Suppliers, Other Farm Service Providers such as Research Institutes, National Agricultural Insurance Company, Agricutural Development Projects, and Nigerian Agricultural Credit Rural Development Bank, among others.

If the partnerships are genuinely going to deliver better quality services, it is vital that they are

designed with the focus on outputs and performance. All the stakeholders or partners need to be clear about what is expected from them and the implications if they fail to deliver. The BPM entails proper role definition and assignments for all stakeholders in the partnership. [i. e. who does what and when- site selection, land preparation etc.]; who pays for what and modalities of payment.

4. Charter of partnership: The charter of partnership among the stakeholders will specify roles of all members based on their capabilities and needs. Issues involving technology to be extended, division of responsibilities, and duration of partnership has to be discussed among stakeholders upon which a Memorandum of Understanding (MOU) would be developed stating distinctly who is to perform what and including penalties for defaulting. The MOU will then be dully signed by the heads of the stakeholders.

The MOU is the legal framework for partnership which should be complemented with social safeguards and social capital development.

BPM is associated with certain benefits: the benefits which have to be mutual should be greater than the benefits that would be obtained if the activities were carried out individually. Such benefits include; Technology transfer; Input and credit linkages; Farmers mobilization; Technical empowerment; Market linkages; Quality control; Production cost can be internationally competitive, risk sharing, enhancement of income, improved level of services.

\section{Application of Commodity Alliance Model}

There are many on-going examples of this model, e.g. OLAM Nig. Ltd, EKHA Agro Farms in Ogun State, MATNA Cassava Processing Mills in Ondo State e.t.c. Also, FIF is providing brokerage services and collaborating with several partners including the Delta State Government. Nevertheless, there is the need to document, research and analyse their performance to perfect, adopt and scale-up operations.

Table 2 presents a catalogue of major agricultural/rural development programmes, interventions models and extension approaches adopted. This is presented to show the relevance of private extension in rural development and possible gaps it can fill. 


\section{Conclusion}

CAM/BPM provides a window of opportunity through which commercialization of extension service delivery could be achieved. The success of this however, will depend on strict professionalization of extension through paradigm shift from its present confine of providing advisory to the process of production to that of input supply, market support and processing.

Further, this model if utilized effectively will make extension agents to become innovation brokers instead of conduits of innovation to the farmers. This will involves building appropriate linkages and facilitate interaction among multi-stakeholders. This will free the agricultural sector from relying on public extension with questionable effectiveness and a limited mandate.

Finally, the capacity farmers' groups, has to be built through Phased Participatory Extension Education System.

Table 2: Agricultural/rural development programmes showing intervention model and extension system adopted

\begin{tabular}{|c|c|c|c|c|}
\hline $\mathbf{S} / \mathbf{N}$ & Name of projects & Model & $\begin{array}{l}\text { Extension } \\
\text { component }\end{array}$ & Remark \\
\hline 1 & FADAMA & CDD & Participatory & On going \\
\hline 2 & $\begin{array}{l}\text { National Special Programme } \\
\text { On Food Security (NSPFS) }\end{array}$ & $\begin{array}{ll}\text { The } & \text { package } \\
\text { approach } & \end{array}$ & Participatory & On going \\
\hline 3 & $\begin{array}{lr}\text { Community } & \text { Service } \\
\text { Development } & \text { Programme( } \\
\text { CSDP) } & \\
\end{array}$ & CDD & Participatory & On going \\
\hline 4 & $\begin{array}{ll}\text { Agricultural } & \text { development } \\
\text { project (ADP) } & \\
\end{array}$ & $\begin{array}{ll}\text { The } & \text { Package } \\
\text { Approach } & \\
\end{array}$ & Participatory & $\begin{array}{l}\text { On going \& state } \\
\text { government sponsored }\end{array}$ \\
\hline 5 & $\begin{array}{lr}\text { Commercial } & \text { Agriculture } \\
\text { Development } & \text { Programme } \\
\text { (CADP) } & \end{array}$ & CDD & Participatory & On going \\
\hline 6 & $\begin{array}{lcr}\text { West Africa } & \text { World Bank } \\
\text { Agricultural } & \text { productivity } \\
\text { Programme } & \text { (WAAPP) }\end{array}$ & $\begin{array}{l}\text { Intersectoral } \\
\text { Approach }\end{array}$ & $\begin{array}{l}\text { Technology } \\
\text { generation and } \\
\text { dissemination }\end{array}$ & World Bank Project \\
\hline 7 & World Food Programme (WFP) & $\begin{array}{l}\text { Intersectoral } \\
\text { Approach }\end{array}$ & $\begin{array}{l}\text { Technology } \\
\text { generation and } \\
\text { dissemination }\end{array}$ & World Bank Project \\
\hline 8 & $\begin{array}{lll}\text { Rural Financial } & \text { Institution } \\
\text { Building Programme } & \text { (RUFIN) } \\
\end{array}$ & $\begin{array}{ll}\text { The } & \text { Package } \\
\text { Approach } & \\
\end{array}$ & Group dynamics & IFAD Project \\
\hline 9 & $\begin{array}{l}\text { Community Based Agricultural } \\
\& \quad \text { Rural Development } \\
\text { Programme (CBARDP) }\end{array}$ & $\begin{array}{ll}\text { The } & \text { Package } \\
\text { Approach } & \end{array}$ & Group dynamics & $\begin{array}{lrrr}\text { IFAD } & \text { Project- } & \text { In } & 8 \\
\text { Northern Nigeria } & & \end{array}$ \\
\hline 10 & $\begin{array}{lc}\text { Community } & \text { Based National } \\
\text { Resources } & \text { Management } \\
\text { Programme } & \text { (CBNRP) } \\
\end{array}$ & $\begin{array}{ll}\text { Rural } & \text { Urban } \\
\text { Interaction } & \end{array}$ & Group dynamics & $\begin{array}{l}\text { IFAD Project }- \text { In Niger } \\
\text { Delta state, Nigeria }\end{array}$ \\
\hline 11 & $\begin{array}{l}\text { Artisan Fisheries Development } \\
\text { Project (AFDP) }\end{array}$ & $\begin{array}{ll}\text { The } & \text { Package } \\
\text { Approach } & \\
\end{array}$ & Group dynamics & IFAD Project \\
\hline 12 & $\begin{array}{l}\text { Root \& Tuber } \\
\text { Project (RTEP) }\end{array}$ & $\begin{array}{ll}\text { The } & \text { Package } \\
\text { Approach } & \\
\end{array}$ & Group dynamics & IFAD Project \\
\hline 13 & $\begin{array}{l}\text { Comprehensive } \\
\text { Agricultural } \\
\text { Programme (CAADP) }\end{array}$ & $\begin{array}{l}\text { The Package } \\
\text { Approach }\end{array}$ & Group dynamics & NEPAD Project \\
\hline 14 & $\begin{array}{lll}\text { National Food } & \text { Reserve } \\
\text { Agency (NFRA) } & \end{array}$ & $M \& E$ & & $\begin{array}{l}\text { Transformed from PCU in } \\
2007\end{array}$ \\
\hline
\end{tabular}




\section{References}

African Institute of Applied Economics (2005) USAID/NIGERIA MARKETS: Evaluation of Rice Alliance Project in Nigeria [Final Report]. 47p.

Audinet. J.and Haralambous.S. 2005. Achieving the Millennium Development Goals: Rural Investment and Enabling Policy. panel discussion paper ifad governing council - Twenty-Eighth Session 16-17 February.

Awoyinka Y. A. (2009). Cassava Mmrketing: Option for sustainable agricultural development in Nigeria. Ozean Journal of Applied Science 2(2), pp. 175 - 183

Ayoola, G. B. (2007). National council of agriculture: Analytical profile of the highest policy making body on agriculture. FIF. Abuja, pp. 62.

CIA (2010). Economy-overview: Nigeria, www.cia.gov/library/publications/the- worldfactbook/[retrieved on 13 March, 2010]

Food Outlook. (2009). Global market analysis, December

Nkama, I., Adamu, D. J. M. and Igene, J. O. (1994) Food loss and conservation under arid environment. Annals of Borno Journal. 11 (12): 191-204

USAID(2005): Rice fact sheet. Info@nigeriamarkets.org www.nigerianstat.gov.ng/ 